\title{
THERAPEUTIC EFFECTS OF CURCUMIN ON MOUSE VENTRICULAR REMODELLING
}

\author{
GUANGNAN LI ${ }^{1}$, YANKUN HAO $^{2}$, SHUANG LI $^{2}$, HONGGUANG LU $^{3}$, FUBO ZHOU $^{4 *}$ \\ ${ }^{I}$ Department of Cardiology, The Fourth Hospital of Harbin Medical University, Harbin, China \\ ${ }^{2}$ Department of Medical Function, Mudanjiang Medical University, Mudanjiang, China \\ ${ }^{3}$ Department of Cardiovascular Surgery, The Fourth Hospital of Harbin Medical University, Harbin, China \\ ${ }^{4}$ Department of Pharmacology, Mudanjiang Medical University, Mudanjiang, China \\ *corresponding author: zhoufubo2013@yeah.net
}

Manuscript received: November 2018

\begin{abstract}
This study aimed to investigate the protective effect of curcumin in ventricular remodelling in a mice model of myocardial infarction. 100 male C57BL/6 mice were randomly divided into a sham group, a model group and a curcumin group (32 mice per group, 4 mice died during the study). The dynamic protein expression of iNOS (inducible nitric oxide synthase), TLR4 (toll-like receptor 4 ) and $\mathrm{p}$-IKK $\alpha / \beta$ (inhibitor of nuclear factor kappa-B kinase) were determined by Western blot and realtime quantitative PCR (RT-PCR). The results showed that after myocardial infarction, the colour of the myocardium was significantly darker than before, and the fibrosis area increased. The protein levels of TLR4 mRNA, TLR4, and iNOS in the mouse myocardial tissues were significantly increased compared to the sham group $(p<0.05)$ associated with a significant increase in inflammatory markers. After curcumin treatment, myocardial morphology recovered and the fibrotic area decreased. The expression level of inflammatory markers in the curcumin group was lower than that in the myocardial infarction group $(p<0.05)$. In conclusion, it was shown that curcumin has an immunomodulatory effect that significantly improves cardiac function after myocardial infarction.
\end{abstract}

\section{Rezumat}

Acest studiu şi-a propus să investigheze efectul protector al curcuminei în remodelarea ventriculară pe un model de şoareci cu infarct miocardic. 100 de şoareci masculi C57BL/6 au fost împărțiți în următoarele grupuri: control negativ, control pozitiv şi grupul curcumină. Expresia dinamică a iNOS, TLR4 și p-IKK $\alpha / \beta$ a fost determinată prin Western blot şi PCR în timp real. Nivelurile mRNA TLR4, TLR4 și iNOS în țesuturile miocardice au fost semnificativ crescute în comparație cu controlul negativ $(\mathrm{p}<0,05)$ asociat cu o creştere semnificativă a markerilor inflamatori. După tratamentul cu curcumină, morfologia miocardică s-a normalizat și zona fibrotică a scăzut. Nivelul expresiei markerilor inflamatori din grupul curcumină a fost mai mic față de controlul pozitiv $(\mathrm{p}<0,05)$. În concluzie, curcumina are un efect imunomodulator care îmbunătățește semnificativ funcția cardiacă după infarctul miocardic.

Keywords: curcumin, ventricular remodelling, myocardial infarction, inflammation

\section{Introduction}

Coronary atherosclerotic heart disease (CHD), also known as coronary heart disease, is one of the major diseases that threaten human health $[1,2]$. As the number of CHD patients increases, the incidence of acute myocardial infarction (AMI) has increased accordingly and is considered to be the leading cause of death and disability [3, 4]. Ventricular remodelling refers to the physiological process of repairing the injury, altering ventricular systolic compensation, and secondary pathology through ventricular regulation and activation after myocardial infarction. Cytokines play an important role in causing morphological changes in cardiomyocytes and other cells, including wall thickness and changes in myocardial structure $[5,6]$.

Curcumin is a small molecular-weight polyphenolic pigment compound commonly used as a pharmacologically active drug [7-9]. Recently, curcumin has attracted the attention of researchers in the cardiovascular field [10, 11], being reported anti-inflammatory, antioxidative and anti-lipidperoxidation effects. However, there are only few studies on the mechanism of action of curcumin in ventricular remodelling after myocardial infarction $[12,13]$.

The current study used a murine model of myocardial infarction to analyse the changes in iNOS, TLR4, pIKK $\alpha / \beta$, and GAPDH (glyceraldehyde-3-phosphate dehydrogenase) proteins expression in myocardial tissues as well as to explore the related indexes of myocardial infarction, myocardial refractive status and the effect of curcumin on ventricular remodelling after myocardial infarction. 


\section{Materials and Methods}

\section{Animals}

A total of 100 male C57BL/6 mice (aged 8 - 10 weeks and weighing 20 - $25 \mathrm{~g}$ ) were purchased from Changsha Tianqin Biotechnology Co., Ltd., China. Animal disposal and experimental procedures comply with the national laboratory animal regulations and the animal experiment was approved by the Ethical Committee of The Fourth Hospital of Harbin Medical University, China. Three mice died before the modelling and the remaining 97 mice were divided into the sham group and the myocardial infarction group as follows: 32 mice were included in the sham group and 65 mice were used for the myocardial infarction model. The mice in the sham group were exposed to thoracotomy without ligating the anterior descending branches.

The myocardial infarction model was obtained as follows: each mouse was anesthetized with $1 \%$ sodium pentobarbital solution (Shantou Guanghua Chemical Plant, China) (50 mg/kg bw) and subsequently fixed in a supine position. The skin from the chest area was disinfected with $75 \%$ alcohol and the area was cleaned by hair. Then, the mice were tracheally intubated by connecting to a small animal ventilator (Instrument Plant of Second Military Medical University, China) (tidal volume of $20 \mathrm{~mL} / \mathrm{kg}$ bw, frequency of 120 times/min). The anterior skin of the mouse was opened, and the chest wall was cut from the third to fourth intercostal space $3-4 \mathrm{~mm}$ to the lower-left atrial appendage and the left anterior descending artery (lad) was ligated with a 7-0 suture needle. The myocardium was white under the ligation site. The chest cavity and the third and fourth ribs were closed using a 6-0 silk thread, and the thoracic muscle was sutured layer by layer. Finally, the chest of the mouse was squeezed to expel the thoracic gas and re-inhale into the lungs for suturing. After the successful establishment of the myocardial infarction model, 1 mouse died and the 64 surviving mice were randomly divided into the myocardial infarction group and curcumin group (curcumin $100 \mathrm{mg} / \mathrm{kg}$ bw/day).

There are three groups in this experiment: I. the sham group (32 mice); II. the myocardial infarction model control group (the MI group) (32 mice); III. the curcumin group (Cur group) (32 mice). Mice in the Sham and MI groups were intraperitoneally injected with $4 \mathrm{~mL} / \mathrm{kg}$ bw/day of a mixture of $6 \%$ ethanol and $6 \%$ polyethylene glycol 400 . The two groups were divided into 4 subgroups as follows: 3 days (A), 7 days (B), 14 days (C), and 28 days (D) after the model was obtained, 8 mice in each subgroup. Mice in the curcumin group were intraperitoneally injected with curcumin solution at a dose of $4 \mathrm{~mL} / \mathrm{kg}$ bw/day (concentration, $25 \mathrm{mg} / \mathrm{mL}$ ), continuously administered for 4 weeks.
Dynamic observation of mice cardiac function changes by echocardiography

After myocardial infarction induction and 28 days of treatment, the mice were anesthetized by $2 \%$ isoflurane administration. Each mouse was placed in a supine position and fixed on a hot plate provided by a Vevo770 ultrasound system (Visualonics, Canada) to maintain a constant body temperature. A B-mode image of the parasternal long axis section and the top four cavity section was collected using a $30 \mathrm{MHz}$ ultrasound probe (Eppendorf, Germany). In addition to the twodimensional ultrasound observation of the left ventricular short-axis section, the sternal left ventricular short-axis section was also analysed. Mmode ultrasound recorded the horizontal movement of the left ventricle to the papillary muscles. The heart rate (HR), left ventricular end-diastolic diameter (LVEDd), left ventricular end-systolic diameter (LVESd), left ventricular ejection fraction (LVEF) and left ventricular shortening fraction (LVFS) were measured.

Total myocardial fibrosis area

Three days after the intervention, mice in the sham group, control group, and the curcumin group 3d subgroup were examined and then sacrificed by cervical dislocation. Similarly, mice in the curcumin group $7 \mathrm{~d}$ subgroup, $14 \mathrm{~d}$ subgroup, and $28 \mathrm{~d}$ group were sacrificed by cervical dislocation after 7,14 and respectively 28 days of treatment. The blood samples were collected directly from the heart and then the hearts were cut and immediately put into the iced saline solution to wash the remaining blood. The morphology of each heart was observed through visual inspection. The left and right auricular appendixes and the macro vessels of the heart were cut. The hearts were dried with filter paper and using an electronic balance. Mouse hearts were fixed in $10 \%$ neutral formalin solution for more than $24 \mathrm{~h}$ and transected between the apex of the coronary arteries. The heart was divided into two equal parts, rinsed with tap water, soaked in double-distilled water for $2 \mathrm{~h}$, and embedded in a waxed section. The infarct size per layer was described as the average percentage of the total length of the intima of the fibrotic intima and the average percentage of the length of the outer membrane of the fibrosis to the total circumference of the outer membrane. The infarct size of the entire heart sample was defined as the mean of the infarct size of each layer.

Detection of total protein and phosphorylation expressions of IKB kinase (IKK) $\alpha / \beta$ by Western blot Mice in the sham group, control group, and the curcumin group $7 \mathrm{~d}$ subgroup (4 mice in each group) were selected, and the total protein of the infarcted myocardium was first extracted. A $100 \mathrm{~mm}$ portion of the tissue block was placed in a homogenizer with $500 \mu \mathrm{L}$ of RIPA lysate (BD, USA). After lysis 
for $30 \mathrm{~min}$, it was centrifuged at $12,000 \mathrm{rpm}$ and $4^{\circ} \mathrm{C}$ for $5 \mathrm{~min}$, and the supernatant was stored at $-20^{\circ} \mathrm{C}$. The protein concentration of the sample was detected using a BCA Protein Assay Kit (Thermo Fisher Scientific, USA). The protein samples extracted from the myocardial tissues of mice were divided in 4 and one part was added to the loading buffer and denatured at $100^{\circ} \mathrm{C}$ for 5 mins and then centrifuged for $15 \mathrm{~s}$. Integral optical density (IOD) was used to measure the value of protein bands. The relative optical density (ROD) was obtained by comparing the IOD of the target band with that of the reference band.

Expressions of TLR4 and inflammation cytokines detected by real-time PCR

Mice in the sham group, the model control group and the curcumin group (4 mice in each group) were selected. $80 \mathrm{mg}$ infarcted myocardium was placed in a glass homogenizer and then homogenized on ice with $1 \mathrm{~mL}$ Triazole solution. Then, $200 \mu \mathrm{L}$ chloroform (Shanghai Beyotime Biotechnology, China) were added and centrifuged for $15 \mathrm{~min}$ at $14,000 \mathrm{~g}$ and the supernatant separated and centrifuged again in the same conditions with chloroform. Then, the supernatant was separated and incubated at room temperature for $30 \mathrm{~min}$ with $0.5 \mathrm{~mL}$ isopropanol (Shanghai Beyotime Biotechnology, China), then, $1 \mathrm{~mL} \mathrm{75 \%}$ ethanol was added and centrifuged for $5 \mathrm{~min}$ at 12,000 g. RNA was washed and precipitated twice. RNA precipitate was dissolved in $10-20 \mathrm{~mL}$ RNAse-free water for integrity identification and concentration and purity analysis.

The QIA rapid gel extraction kit (Eppendorf, Germany) was used for recovery and purification. The concentration was calculated based on OD260 measurements and fragment length data of positive standards. The following reaction systems were used for the samples and positive standards (Table I). The mRNA was detected by using an ABI (Applied Biosystems) fluorescence quantitative PCR machine (ABI Corporation, USA). During the PCR, the sample was denatured for $10 \mathrm{~s}$ at $95^{\circ} \mathrm{C}$, renatured for $31 \mathrm{~s}$ at $60^{\circ} \mathrm{C}$, and extended for $50 \mathrm{~s}$ at $68^{\circ} \mathrm{C}$, with a total of 40 cycles.

The primers of target gene sequences were summarized as follows:

TLR4: F-GCTTTCACCTCTGCCTTCAC; R-CGAGGCTTTTCCATCCAATA;

IL-1 $\beta$ : F-TTGGGCCTCAAAGGAAAGAAT;

R-TGGGTATTGCTTGGGATCCA;

TNF- $\alpha: \quad F-G C C A A C G G C A T G G A T C T C$;

R-GCAGCCTTGTCCCTTGAAGAG;

IL-6 : F-GCTAAGGACCAAGACCATCCAAT;

R-GGCATAACGCACTAGGTTTGC;

IL-10: F-GCCAAGCCTTATCGGAAATG; R-GGGAATTCAAATGCTCCTTGAT.
Table I

Reaction system of real-time fluorescent

\begin{tabular}{lc}
\multicolumn{1}{c}{ Component } & Volume \\
\hline DEPC·H2O & $4 \mu \mathrm{L}$ \\
SYBR Green PCR Master Mix & $10 \mu \mathrm{L}$ \\
Upstream primer & $0.5 \mu \mathrm{L}$ \\
Downstream primer & $0.5 \mu \mathrm{L}$ \\
Total volume & $15 \mu \mathrm{L}$ \\
\hline
\end{tabular}

\section{Statistics analysis}

SPSS 13.0 statistical software (IBM, USA) package was used for statistical analysis. All the results were expressed as mean \pm standard deviation $(\mathrm{x} \pm \mathrm{s}$ ). Singlefactor analysis of variance was used for comparison among groups. The Least Significant Difference method (LSD) was used to compare the variances between groups when the variances were the same; otherwise the Welch test was used. Dunnet's T3 test was used to compare the differences among groups. A value of $\mathrm{p}<0.05$ was considered to be statistically significant.

\section{Results and Discussion}

Cardiac morphology after myocardial infarction in mice

The cardiac morphology of the sham group had a smooth heart surface, normal shape and volume of the ventricle, a uniform wall thickness, good elasticity and reddish surface colour. In contrast, the heart of the model group and the infarcted area were not smooth. Fibrosis of the myocardium leads to the loss of original shape and elasticity. The walls of the chamber became thicker and the surface was shrunken and was dark red. The heart shape of the curcumin group was augmented to that of the myocardial infarction group. However, the colour was still dark red and the surface elasticity was very weak. The wall of the myocardial infarction group was thinner than the curcumin group.

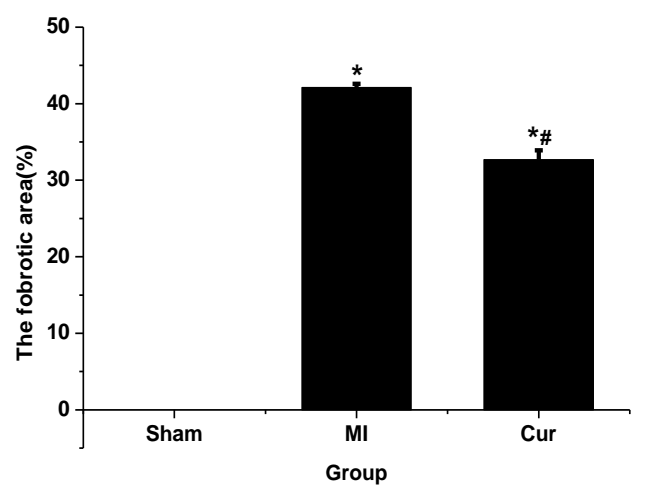

Figure 1.

Comparison of fibrosis area of mice in each group (*p $<0.05$ compared with the sham group; \#p $<0.05$ compared with the MI group) 
FARMACIA, 2019, Vol. 67, 6

Analysis of fibrosis area after myocardial infarction in mice

The myocardial fibrosis area in each group is shown in Figure 1. In the sham group, there was no myocardial fibrosis, while the myocardial fibrosis area in the MI group and the curcumin group was significantly increased $(\mathrm{p}<0.05)$. It is worth noting that compared with the model group, the myocardial fibrosis area of the curcumin group was significantly reduced, and the difference was significant $(\mathrm{p}<0.05)$.

Effects of curcumin on cardiac function after MI in mice

After 28 days from MI and treatment, there were significant differences in ultrasonic cardiogram (UCG)

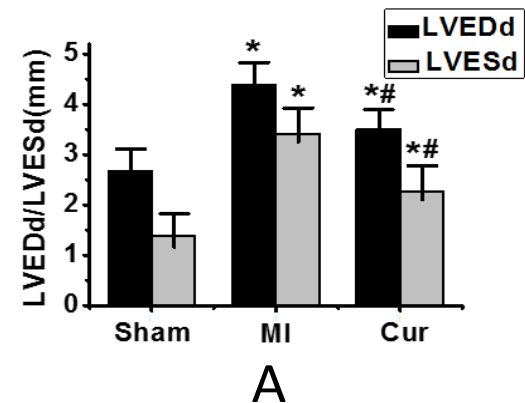

cardiac function indexes LVEDd, LVESd, LVEF and LVFS between each group ( $<<0.05)$ (Figure 2). Compared with the sham group, the LVEDd and LVESd of the MI group and the curcumin group were significantly increased ( $\mathrm{p}<0.05)$, while the LVEF and LVFS were significantly decreased $(\mathrm{p}<0.05)$, indicating that the systolic and diastolic functions of the heart were obviously damaged by coronary artery ligation. Compared with the MI group, LVEDd and LVESd were significantly decreased in the curcumin group, while LVEF and LVFS were significantly increased $(\mathrm{p}<0.05)$.

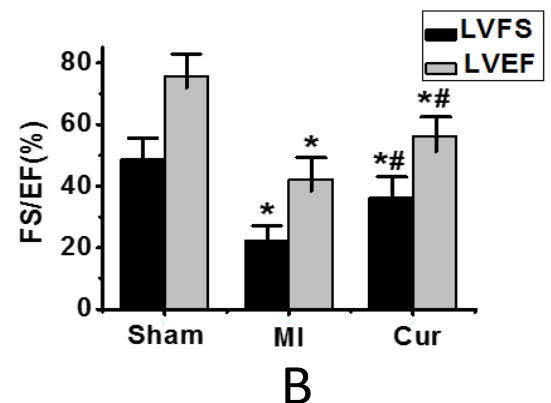

Figure 2.

The effect of curcumin on mice cardiac function

A) diameters of the left ventricular diastolic/end-systolic period; B) left ventricular ejection/short-axis shortening scores $(* \mathrm{p}<0.05$ compared with the sham group; $\# \mathrm{p}<0.05$ compared with the model control group; $\mathrm{n}=4$ )

Effects of curcumin on iNOS, TLR4 and IKK $\alpha / \beta$ protein in the myocardium

In Figure 3B and Figure 3C, compared with the sham group, the TLR4 mRNA and protein levels in the infarcted myocardium from the MI and curcumin groups were significantly increased $(p<0.05)$. Compared with MI group, the TLR4 mRNA and protein levels in the curcumin group were significantly decreased $(\mathrm{p}<0.05)$ (Figure 3B and Figure 3C). The iNOS protein level in the mice infarcted myocardium of the MI group and curcumin group was significantly increased compared with the sham group $(p<0.05)$ (Figure 3D). Compared with the MI group, the expression level of iNOS in the curcumin group was significantly decreased $(\mathrm{p}<0.05)$ (Figure 3D). The phosphorylation levels of IKB $\alpha$ and IKK $\alpha / \beta$ were increased significantly in the MI model control group compared with the sham group $(\mathrm{p}<0.05)$, while the curcumin treatment decreased the phosphorylation levels of IKB $\alpha$ and IKK $\alpha / \beta$ significantly $(p<0.05)$ (Figure 3E and Figure 3F).
Effects of curcumin on inflammatory cytokines in the myocardium after $M I$

The results showed that the mRNA expressions of pro-inflammatory cytokine IL- $1 \beta$, TNF- $\alpha$, and IL-6 increased in the infarcted myocardium of mice in the MI group compared with the sham group (the $3 \mathrm{~d}$ group only was taken as control group), herein those of the $3 \mathrm{~d}$ group were the highest. The mRNA expressions of pro-inflammatory cytokines IL- $1 \beta$, TNF- $\alpha$ and IL- 6 in the infarcted myocardium of mice in the $7 d$ group decreased, while the $28 \mathrm{~d}$ group basically returned to normal (Figure 4). The mRNA expressions of proinflammatory cytokines IL- $1 \beta$, TNF- $\alpha$ and IL- 6 in infarcted myocardium of mice from the curcumin group were decreased compared to the MI group in $3 d$ and $7 d$ subgroups $(p<0.05)$, while in the $28 d$ subgroup they returned almost to the values of the sham group. The levels of anti-inflammatory cytokine IL-10 were constant in the $3 \mathrm{~d}$ and $7 \mathrm{~d}$ groups, while in the $28 \mathrm{~d}$ group increased significantly in both MI and curcumin group compared to the sham group $(\mathrm{p}<0.05)$. No difference in IL-10 levels was observed between curcumin and MI groups (Figure 4). 


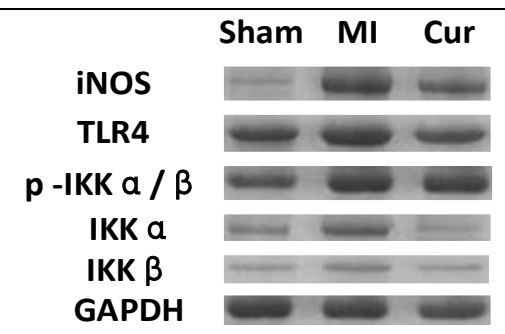

A
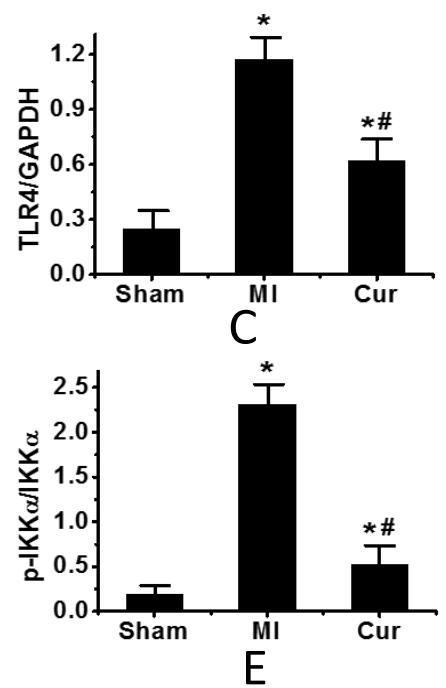

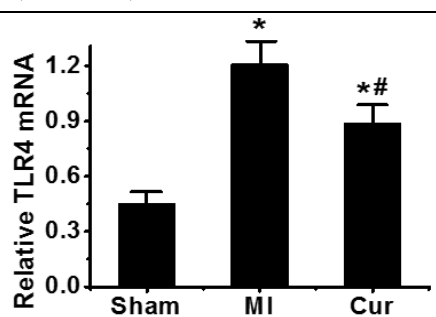

B
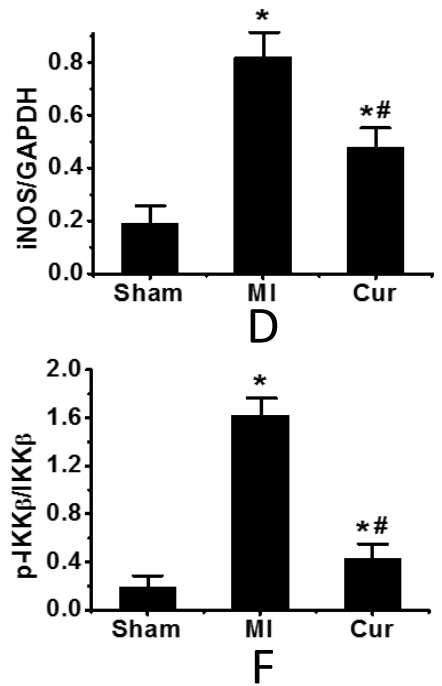

Figure 3.

Expressions of related proteins and mRNA in infarcted myocardium of mice in the $7 \mathrm{~d}$ subgroup A) electrophoretogram of iNOS, TLR4, p-IKK $\alpha / \beta$ and GAPDH protein levels detected by Western Blot; B) TLR4 protein expression levels; C) TLR4 mRNA expression levels; D) iNOS protein expression levels; E) IKK $\alpha$ protein expression levels; F) IKK $\beta$ protein expression levels; ( ${ }^{*} \mathrm{p}<0.05$ compared with the sham group; $\# \mathrm{p}<0.05$ compared with the MI group; $\mathrm{n}=4$ )
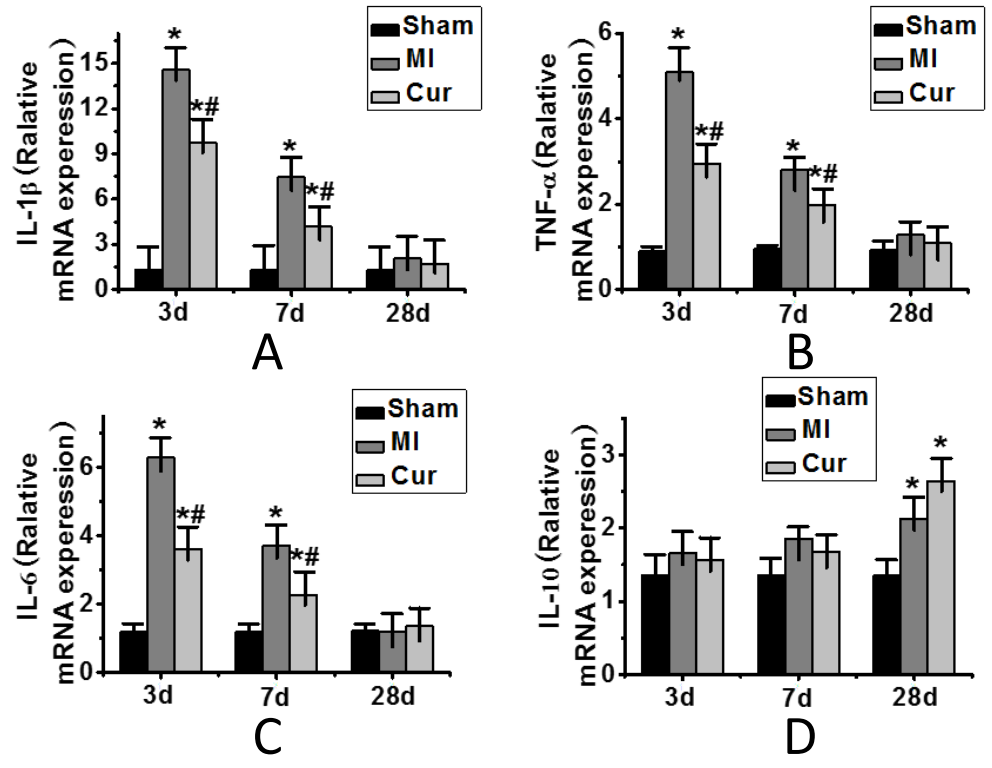

Figure 4.

Effects of curcumin on cytokines in infarcted myocardium

A) IL-1 $\beta$ mRNA expression levels; B) TNF- $\alpha$ mRNA expression levels; C) IL-6 mRNA expression levels; D) IL-10 mRNA expression levels; ( $* \mathrm{p}<0.05$ compared with the sham group; \#p $<0.05$ compared with the MI group; $\mathrm{n}=4$ )

Due to changes in myocardial function, the myocardial contraction terminal volume increases, the ventricular cavity expands, the ventricle is spherical, and the left ventricular ejection fraction is reduced by molecular and cellular mechanisms. It should not be overlooked that ventricular remodelling is a complex pathological process [14]. Therefore, various physiological heart diseases develop into heart failure and even lead to 
death $[15,16]$. In this study, by observing changes in the structure and function of the mouse heart, it was found that the cardiac morphology of the myocardial infarction group was significantly changed, the colour was darkened, and myocardial fibrosis was significantly aggravated in the myocardial infarction group.

However, after the treatment with curcumin, the myocardial fibrosis area was significantly reduced. Ventricular remodelling is an essential pathophysiological process in which myocardial infarction develops into heart failure and persists throughout the disease, and is one of the main factors affecting the long-term prognosis of AMI patients $[17,18]$. However, after the activation of the innate immune mechanism, various chemokines tend to be increased. For example, the tumour necrosis factor-alpha (TNF- $\alpha$ ) and interleukin can activate the complement and stimulate DNA translation, DNA transcription, as well as protein synthesis. However, due to their excessive expression, heart failure may appear $[19,20]$. In this study, the levels of TLR4 mRNA, TLR4, iNOS protein phosphorylation levels of IKB $\alpha$ and IKK $\alpha / \beta$ in the MI group were significantly increased $(\mathrm{p}<0.05)$, which was consistent with previous studies [19, 20]. Curcumin inhibits the expression of iNOS, TLR4, and other proteins in infarcted myocardium after MI, thereby inhibiting the inflammatory responses. Moreover, in the process of ventricular remodelling, curcumin is added as an intervention to reduce the possibility of MI.

\section{Conclusions}

Curcumin has an immunomodulatory effect that significantly improves cardiac function after myocardial infarction.

\section{Acknowledgement}

This work was supported by The Scientific research projects of basic scientific research in colleges and universities operating expenses of Heilongiiang Province in 2018, China (Grant No. 2018-KYYWFMY-0014); and the Health Commission of Heilongjiang Province Project (2014-376).

\section{References}

1. Chaanine AH, Sreekumaran Nair K, Bergen RH $3^{\text {rd }}$, Klaus K, Guenzel AJ, Hajjar RJ, Redfield MM, Mitochondrial integrity and function in the progression of early pressure overload-induced left ventricular remodeling. J Am Heart Assoc., 2017; 6(6): e005869: 1-18.

2. Sanchis-Gomar F, Perez-Quilis C, Leischik R, Lucia A, Epidemiology of coronary heart disease and acute coronary syndrome. Ann Transl Med., 2016; 4(13): 256: 1-12.

3. Yue DY, Jiang YD, Cao L, Shen HY, Yang ZY, Antiatherosclerotic effect of rosuvastatin by modulation of
MGF-E8 and klotho expression. Farmacia, 2018; 66(3): 530-536.

4. Liu J, Zhu Y, Liu Y, Liu J, Wu Y, Luo S, Zhou X, Hao Y, Correlation between alcohol consumption and myocardial infarction: Dose-response meta-analysis of 18 cohort studies. Farmacia, 2017; 65(1): 5-13.

5. Omboni S, Posokhov I, Parati G, Rogoza A, Kotovskaya Y, Arystan A, Avolio A, Barkan V, Bulanova N, Cardona Muñoz E, Grigoricheva E, Konradi A, Minyukhina I, Muiesan ML, Mulè G, Orlova I, Pereira T, Peixoto Maldonado JM, Statsenko ME, Tilea I, Waisman G, VASOTENS Registry Study Group, Ambulatory blood pressure and arterial stiffness web-based telemonitoring in patients at cardiovascular risk. First results of the VASOTENS (Vascular health ASsessment Of The hypertENSive patients) Registry. $J$ Clin Hypertens (Greenwich), 2019; 21(8): 1155-1168.

6. Zarrouk-Mahjoub S, Zaghdoudi M, Amira Z, Chebi H, Khabouchi N, Finsterer J, Mechmeche R, Ghazouani E, Pro- and anti-inflammatory cytokines in postinfarction left ventricular remodeling. Int J Cardiol., 2016; 221: 632-636.

7. Oyemitan IA, Elusiyan CA, Onifade AO, Akanmu MA, Oyedeji AO, McDonald AG, Neuropharmacological profile and chemical analysis of fresh rhizome essential oil of Curcuma longa (turmeric) cultivated in Southwest Nigeria. Toxicol Rep., 2017; 4: 391-398.

8. Wongcharoen $\mathrm{W}$, Phrommintikul A, The protective role of curcumin in cardiovascular diseases. Int $J$ Cardiol., 2009; 133(2): 145-151.

9. Panahi Y, Ahmadi Y, Teymouri M, Johnston TP, Sahebkar A, Curcumin as a potential candidate for treating hyperlipidemia: a review of cellular and metabolic mechanisms. J Cell Physiol., 2018; 233(1): 141-152.

10. Mirzabeigi P, Mohammadpour AH, Salarifar M, Gholami K, Mojtahedzadeh M, Javadi MR, The Effect of Curcumin on some of Traditional and Nontraditional Cardiovascular Risk Factors: A Pilot Randomized, Double-blind, Placebo-controlled Trial. Iran J Pharm Res., 2015; 14(2): 479-486.

11. Qin S, Huang L, Gong J, Shen S, Huang J, Ren H, Hu $\mathrm{H}$, Efficacy and safety of turmeric and curcumin in lowering blood lipid levels in patients with cardiovascular risk factors: a meta-analysis of randomized controlled trials. Nutr J., 2017; 16(1): 68: 1-10.

12. Li C, Miao X, Li F, Adhikari BK, Liu Y, Sun J, Zhang R, Cai L, Liu Q, Wang Y, Curcuminoids: Implication for inflammation and oxidative stress in cardiovascular diseases. Phytother Res., 2019; 33(5): 1302-1317.

13. Farkhondeh T, Samarghandian S, Antidotal effects of curcumin against agents-induced cardiovascular toxicity. Cardiovasc Hematol Disord Drug Targets, 2016; 16(1): 30-37.

14. Wei BR, Neelamegham S, Selectins and immune cells in acute myocardial infarction and postinfarction ventricular remodeling: pathophysiology and novel treatments. Front Immunol., 2019; 10: 300: 1-15.

15. Bradham WS, Bell SP, Huang S, Harrell FEJr, Adkisson DW, Lawson MA, Sawyer DB, Ooi H, Timing of Left Ventricular Remodeling in Non- 
ischemic Dilated Cardiomyopathy. Am J Med Sci., 2018; 356(3): 262-267.

16. Yamaguchi T, Izumi Y, Nakamura Y, Yamazaki T, Shiota M, Sano S, Tanaka M, Osada-Oka M, Shimada K, Miura K, Yoshiyama M, Iwao H, Repeated remote ischemic conditioning attenuates left ventricular remodeling via exosome-mediated intercellular communication on chronic heart failure after myocardial infarction. Int J Cardiol., 2015; 178: 239-246.

17. Fujita A, Takahashi-Yanaga F, Morimoto S, Yoshihara T, Arioka M, Igawa K, Tomooka K, Hoka S, Sasaguri T, 2,5-Dimethylcelecoxib prevents pressure-induced left ventricular remodeling through GSK-3 activation. Hypertens Res., 2017; 40(2): 130-139.

18. Westman PC, Lipinski MJ, Luger D, Waksman R, Bonow RO, Wu E, Epstein SE, Inflammation as a driver of adverse left ventricular remodeling after acute myocardial infarction. J Am Coll Cardiol., 2016; 67(17): 2050-2060.

19. Zhang X, Yang K, Zhang H, Dong W, Peng W, Zhao $\mathrm{Y}$, Effect of typhaneoside on ventricular remodeling and regulation of PI3K/Akt/mTOR pathway. Herz, 2019; $1-10$.

20. Rordorf R, Savastano S, Sanzo A, Spazzolini C, De Amici M, Camporotondo R, Ghio S, Vicentini A, Petracci B, De Regibus V, Taravelli E, Landolina M, Schwartz PJ, Tumor necrosis factor-alpha predicts response to cardiac resynchronization therapy in patients with chronic heart failure. Circ J., 2014; 78(9): 2232-2239. 